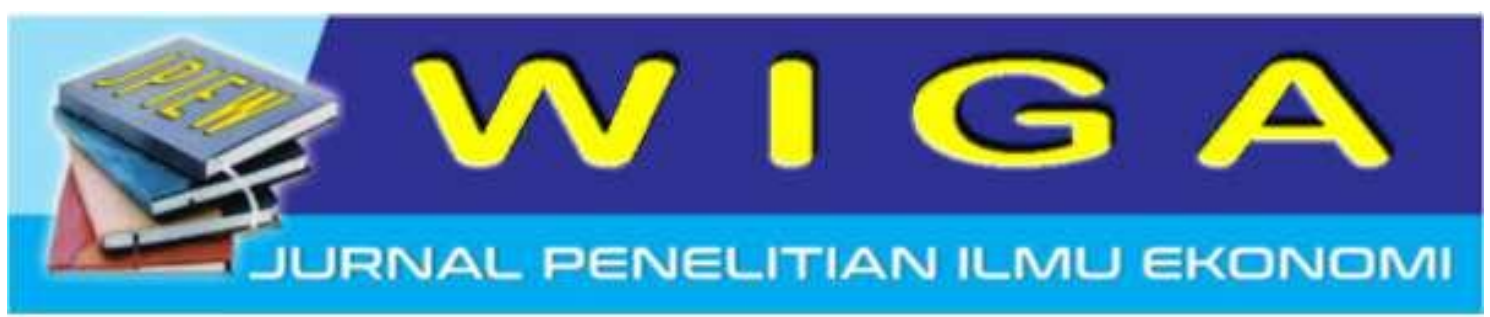

\title{
Pengaruh Lingkungan Kerja, Motivasi Kerja Dan Stres Kerja Terhadap Kinerja Pegawai
}

\author{
Lindu Prabowo ${ }^{1}$ \\ ${ }^{1}$ Mahasiswa Program Studi Magister Manajemen, Universitas Merdeka Malang, Indonesia \\ linduprabowo@gmail.com
}

Anwar Sanusi ${ }^{2}$

Tanto Sumarsono ${ }^{3}$

Dosen Fakultas Ekonomi dan Bisnis, Universitas Merdeka Malang, Indonesia

\begin{abstract}
Abstrak
Tujuan penelitian ini adalah Untuk mendeskripsikan variabel Lingkungan Kerja, Motivasi, Stres Kerja dan Kinerja Karyawan. Populasi dalam penelitian ini berjumlah 56 orang. Untuk mengumpulkan data peneliti menggunakan kuesioner. Untuk analisis deskriptif dan regresi, SPSS versi 20 diterapkan. Berdasarkan hasil penelitian menunjukkan bahwa 1). Lingkungan kerja tidak berpengaruh signifikan terhadap kinerja karyawan, karena budaya lingkungan kerja sudah mapan 2). Motivasi kerja mempengaruhi kinerja karyawan, semakin baik motivasi semakin baik kinerja karyawan, 3). Stres kerja mempengaruhi kinerja karyawan, semakin banyak stres meningkatkan semakin meningkatkan kinerja karyawan, 4). Motivasi adalah variabel yang memiliki pengaruh dominan terhadap kinerja karyawan, sehingga motivasi harus dipertimbangkan dengan baik oleh pemimpin.
\end{abstract}

Keyword: Lingkungan Kerja, Motivasi, Jos Stress, dan Kinerja Karyawan

\begin{abstract}
The purpose of this study is To describe the variables Work Environment, Motivation, Job Stress and Employee Performance. The population in this study amounted to 56 people. To collect the data the researcher used questionnaires. For descriptive and regresion analysis SPSS version 20 were applied. Based on the result of research indicate that 1). Work environment does not significantly affect employee performance, because the work environment culture is well established 2). Motivation of work affect the performance of employees, the better the motivation the better the performance of employees, 3). Job stress affects the performance of employees, the more stress increases the more increases the performance of employees, 4). Motivation is a variable that has a dominant influence on employee performance, so the motivation must be considered well by the leader.
\end{abstract}

Keyword : Work Environment, Motivation, Jos Stress, and Employee Performance

\section{PENDAHULUAN}

Sumber daya manusia merupakan aset yang berharga dalam mencapai tujuan organisasi. Kemajuan suatu organisasi sangat tergantung pada kualitas sumber daya manusianya. Setiap organisasi membutuhkan sumber daya manusia yang memiliki kinerja yang tinggi agar dapat bertahan dalam persaingan usaha yang semakin ketat. Tuntutan organisasi atas kinerja Pegawai yang baik dan terus meningkat seringkali menyebabkan stres yang akhirnya berdampak pada kinerja. Stres kerja merupakan salah satu faktor yang dapat menyebabkan Pegawai merasa tertekan dalam pekerjaan sehingga dapat menghasilkan hambatan proses berfikir, emosional, dan gangguan pada kondisi fisik. Jika stres bertambah, maka akan semakin mempengaruhi kinerja dan kesehatannya, bahkan dapat menyebabkan gangguan untuk berkomunikasi dengan lingkungan sekitarnya.

Organisasi di dalam perkembangannya selalu melakukan perubahan untuk mengatasi hal-hal yang dapat menghambat kinerja

WIGA : Jurnal Penelitian IImu Ekonomi, Volume 8 Nomor 1 | 24 
Pegawai, salah satunya mengetahui sumber dari hambatan tersebut. Menurut Luthans (2003:8) mengatakan bahwa secara umum stres kerja timbul karena tuntutan lingkungan dan tanggapan setiap individu dalam menghadapinya dapat berbeda. Dalam kondisi saat ini, perubahan lingkungan bisnis, baik teknologi, politik, ekonomi sangat berpengaruh pada organisasi, khususnya dalam menghadapi persaingan. Pada umumnya organisasi yang tidak mampu menghadapi persaingan memiliki kinerja dan kualitas produk yang rendah. Untuk mampu membawa organisasi dalam memasuki lingkungan bisnis, pimpinan harus bertanggung jawab untuk merencanakan dan memiliki kompetensi untuk melakukan perubahan sesuai dengan yang diharapkan. Kesuksesan suatu organisasi dalam mengelola sumber daya manusia yang dimiliki sangat menentukan keberhasilan pencapaian tujuan organisasi. Setiap organisasi akan selalu berusaha untuk meningkatkan kinerja Pegawainya, dengan harapan apa yang menjadi tujuan organisasi akan tercapai. Sumber daya terpenting bagi suatu perusahaan atau organisasi adalah sumber daya manusia yaitu orang yang telah memberikan tenaga, bakat, kreativitas dan usaha mereka pada organisasi (Handoko, 2001:133).

Tujuan yang ingin dicapai organisasi tidak akan terlepas dari peran setiap Pegawai yang menjadi penggerak kehidupan organisasi, sehingga sudah selayaknya peran dari pimpinan organisasi untuk dapat memahami kondisi para Pegawaiya, apabila terdapat beban masalah yang dapat menghambat kinerja organisasi maka secepatnya pimpinan dapat mengurangi dan meyelesaikan masalah tersebut, terutama mengenai stres kerja yang semestinya harus dikelola dengan penuh kesinambungan supaya tidak menghambat jalannya kinerja organisasi.Menurut Robbins (2003:86) lingkungan adalah lembagalembaga atau kekuatan-kekuatan diluar yang berpotensi mempengaruhi kinerja organisasi, lingkungan dirumuskan menjadi dua yaitu lingkungan umum dan lingkungan khusus. Lingkungan umum adalah segala sesuatu di luar organisasi yang memiliki potensi untuk mempengaruhi organisasi. Lingkungan ini berupa kondisi sosial dan teknologi. Sedangkan lingkungan khusus adalah bagian lingkungan yang secara langsung berkaitan dengan pencapaian sasaran-sasaran sebuah organisasi.

Terlepas dari stres dan lingkungan kerja, motivasi pegawai adalah hal yang tidak bisa dipisahkan dengan peningkatan kinerja pegawai. Motivasi merupakan faktor yang sangat menentukan kinerja Griffin (2003:38). Motivasi merupakan dorongan, keinginan, hasrat dan tenaga penggerak yang berasal dari diri manusia untuk berbuat atau untuk melakukan sesuatu (Wursanto, 2005:301) .Jadi pada dasarnya apabila organisasi ingin meraih kinerja yang optimal sesuai dengan target yang telah di tentukan maka organisasi haruslah memberikan motivasi pada pegawai agar pegawai mau dan rela mencurahkan tenaga dan pikiran yang dimiliki demi pekerjaan. Persoalan dalam memotivasi pegawai tidak mudah karena dalam diri pegawai terdapat keinginan, kebutuhan dan harapan yang berbeda antara satu pegawai dengan pegawai lain. Jadi apabila manajemen dapat memahami persoalan motivasi dan mengatasinya maka perusahaan akan mendapatkan kinerja pegawai yang optimal sesuai dengan standar yang di tentukan.

Mathis (2006:378) kinerja dipengaruhi beberapa faktor diantaranya adalah kuantitas pekerjaan yang dapat dilakukan oleh seseorang dalam waktu satu hari kerja, kualitas dalam ketaatan dalam prosedur dan disiplin, keandalan dalam melakukan pekerjaan yang diisyaratkan dengan supervisi minimum, kehadiran masuk kerja setiap hari dan sesuai jam kerja, dan kemampuan bekerja sama dengan orang lain dalam menyelesaikan tugas dan pekerjaan yang telah ditetapkan sehingga mencapai daya guna yang sebesarbesarnya.

\section{KAJIAN PUSTAKA}

a. Kinerja

Menurut Mangkunegara (2006:67) bahwa kinerja (prestasi kerja) adalah hasil kerja secara kualitas dan kuantitas yang dicapai oleh seorang pegawai dalam melaksanakan tugasnya sesuai dengan tanggung jawab yang diberikan kepadanya. Tiga dimensi kinerja yang dipakai dalam penelitian ini mengacu pada Mangkunegara (2006:67), yaitu:

1). Bekerja tanpa kesalahan (kualitas kerja) yaitu tidak melakukan kesalahan terhadap pekerjaan merupakan tuntutan bagi setiap Pegawai.

2). Penyelesaian pekerjaan melebihi target (kuantitas pekerjaan) yaitu apabila Pegawai menyelesaikan pekerjaan melebihi target yang ditentukan oleh organisasi.

3). Ketepatan waktu dalam meyelesaikan tugas yaitu kesanggupan Pegawai menyelesaikan pekerjaan tepat waktu.

b. Lingkungan Kerja

Menurut Sedarmayanti (2009:31) lingkungan kerja fisik adalah semua keadaan berbentuk fisik yang terdapat di sekitar tempat kerja yang dapat mempengaruhi Pegawai baik secara langsung maupun secara tidak langsung. 
Sedangkan lingkungan kerja nonfisik adalah semua keadaan yang terjadi berkaitan dengan hubungan kerja, baik hubungan dengan atasan maupun dengan rekan kerja, ataupun hubungan dengan bawahan. Dimensi lingkungan kerja yang digunakan dalam penlitian ini mengacu pada pendapat Sedarmayanti (2009:28) diantaranya :

1). Penerangan/cahaya di tempat kerja

Cahaya atau penerangan sangat besar manfaatnya bagi pegawai guna mendapat keselamatan dan kelancaran kerja, oleh sebab itu perlu diperhatikan adanya penerangan (cahaya) yang terang tetapi tidak menyilaukan. Cahaya yang kurang jelas (kurang cukup) mengakibatkan penglihatan menjadi kurang jelas, sehingga pekerjaan akan lambat, banyak mengalami kesalahan, dan pada akhirnya menyebabkan kurang efisien dalam melaksanakan pekerjaan, sehingga tujuan organisasi sulit tercapai.

2). Sirkulasi udara ditempat kerja

Oksigen merupakan gas yang dibutuhkan oleh makhluk hidup untuk menjaga kelangsungan hidup, yaitu untuk proses metabolisme. Udara di sekitar dikatakan kotor apabila kadar oksigen dalam udara tersebut telah berkurang dan telah bercampur dengan gas atau bau-bauan yang berbahaya bagi kesehatan tubuh. Sumber utama adanya udara segar adalah adanya tanaman disekitar tempat kerja. Tanaman merupakan penghasil oksigen yang dibutuhkan oleh manusia.

3). Kebisingan di tempat kerja

Salah satu polusi yang cukup menyibukkan para pakar untuk mengatasinya adalah kebisingan, yaitu bunyi yang tidak dikehendaki oleh telinga. Tidak dikehendaki, karena terutama dalam jangka panjang bunyi tersebut dapat mengganggu ketenangan bekerja, merusak pendengaran, dan menimbulkan kesalahan komunikasi, bahkan menurut penelitian, kebisingan yang serius dapat menyebabkan kematian.

4). Bau tidak sedap di tempat kerja

Adanya bau-bauan di sekitar tempat kerja dapat dianggap sebagai pencemaran, karena dapat mengganggu konsentrasi bekerja, dan bau-bauan yang terjadi terus-menerus dapat mempengaruhi kepekaan penciuman. Pemakaian "air condition" yang tepat merupakan salah satu cara yang dapat digunakan untuk menghilangkan bau-bauan yang mengganggu disekitar tempat kerja.

5). Keamanan di tempat kerja

Guna menjaga tempat dan kondisi lingkungan kerja tetap dalam keadaan aman maka perlu diperhatikan adanya keamanan dalam bekerja. Oleh karena itu faktor keamanan perlu diwujudkan keberadaannya. Salah satu upaya untuk menjaga keamanan ditempat kerja, dapat memanfaatkan tenaga Satuan Petugas Pengaman (SATPAM).

c. Motivasi Kerja

1). Kebutuhan fisiologis (Physiologicalneed)

Kebutuhan Fisiologis Kebutuhan fisiologis merupakan hirarki kebutuhan manusia yang paling dasar yang merupakan kebutuhan untuk dapat hidup seperti makan, minum, perumahan, oksigen, tidur dan sebagainya.

2). Kebutuhan rasa aman (Safety-need) Apabila kebutuhan fisiologis relatif sudah terpuaskan, maka muncul kebutuhan yang kedua yaitu kebutuhan akan rasa aman. Kebutuhan akan rasa aman ini meliputi keamanan akan perlindungan dari bahaya kecelakaan kerja, jaminan akan kelangsungan pekerjaannya dan jaminan akan hari tuanya pada saat mereka tidak lagi bekerja.

3). Kebutuhan sosial (Social-need)

Jika kebutuhan fisiologis dan rasa aman telah terpuaskan secara minimal, maka akan muncul kebutuhan sosial, yaitu kebutuhan untuk persahabatan, afiliasi dana interaksi yang lebih erat dengan orang lain. Dalam organisasi akan berkaitan dengan kebutuhan akan adanya kelompok kerja yang kompak, supervisi yang baik, rekreasi bersama dan sebagainya.

4). Kebutuhan penghargaan (Esteemneed)

Kebutuhan ini meliputi kebutuhan keinginan untuk dihormati, dihargai atas prestasi seseorang, pengakuan atas kemampuan dan keahlian seseorang serta efektifitas kerja seseorang.

5). Kebutuhan aktualisasi diri (Selfactualization need)

Aktualisasi diri merupakan hirarki kebutuhan dari Maslow yang paling tinggi. Aktualisasi diri berkaitan dengan proses pengembangan potensi yang sesungguhnya dari seseorang. Kebutuhan untuk menunjukkan kemampuan, keahlian dan potensi yang dimiliki seseorang. Malahan kebutuhan akan aktualisasi diri ada kecenderungan potensinya yang meningkat karena orang mengaktualisasikan perilakunya. Seseorang yang didominasi oleh kebutuhan akan aktualisasi diri senang akan tugas-tugas yang menantang kemampuan dan keahliannya.

d. Stres Kerja 
Luthans (2003:8) mendefinisikan Stres was opinion to make problem solving which was influenced by differences of individuals and psychological process was as consequence and behavior of environment, situation, events which needs demand of someone's psychological and physical. Secara umum stres kerja timbul karena tuntutan lingkungan dan tanggapan setiap individu dalam menghadapinya dapat berbeda. Masalah stres kerja di dalam organisasi menjadi masalah yang penting untuk diamati sejak mulai timbulnya tuntutan untuk efisiensi dalam pekerjaan. Akibat dari stres orang menjadi nervous merasa kecemasan kronis, peningkatan ketegangan pada emosi, proses berfikir dan kondisi fisik individu. Selain itu hasil dari stres dapat mengancam dan mengganggu pelaksanaan kerja Pegawai seperti mudah marah dan agresif, tidak dapat relax, emosi tidak stabil, sikap tidak mau bekerjasama, perasaan tidak mampu terlibat dan kesulitan dalam masalah tidur.Stres kerja adalah kondisi ketegangan yang mempengaruhi emosi, proses berpikir, dan kondisi seseorang dalam melaksanakan pekerjaan (Handoko, 2001:201). Adapun dimensidimensi Stres Kerja, sebagai berikut (Handoko, 2008:200) :

1. Beban kerja berlebihan

2. Tekanan atau desakan waktu

3. Kualitas supervise yang jelek

\section{METODE PENELITIAN}

a. Desain penelitian.

Berdasarkan tujuan penelitian ini, maka desain penelitian adalah desain penelitian kausalitas untuk mengukur kemungkinan adanya hubungan sebab akibat antar variabel. Pendekatan yang digunakan dalam penelitian ini adalah pendekatan kuantitatif, yang prosesnya diawali dengan penyusunan model teoritis dan analisis sebagai dasar pengajuan pertanyaan sementara (hipotesis), kemudian dilanjutkan dengan operasionalisasi konsep, sampai penyimpulan sebagai suatu temuan penelitian.

b. Populasi

Populasi dalam penelitian ini adalah seluruh pegawai di lingkungan Dinas Perpustakaan dan Kearsipan Kabupaten Malang yang berjumlah 56 orang. Untuk mendapatkan generalisasi data yang lebih baik, maka digunakan sensus yaitu mengambil seluruh anggota dari populasi.

c. Teknik pengumpulan data
Wawancara dan mendistribusikan kuesioner untuk dijawab. Jawaban kuesioner disajikan menurut skala Likert dengan pilihan poin 5. Poin tertinggi menyatakan persepsi sangat setuju hingga poin terendah menyatakan sangat tidak setuju. Hasil tabulasi data diuji validitas dan reliabilitas.

d. Variabel dan indikator

Hubungan antara indikator dengan variabel laten adalah reflektif, maka perlu dihitung nilai skor faktor untuk masingmasing variabel terlebih dahulu dibantu dengan program SPSS. Untuk membuktikan hipotesis penelitian dilakukan dengan analisis regresi untuk masing-masing nilai skor faktor variabel bebas terhadap variabel terikat.

Variabel bebas lingkungan kerja diukurdengan 5 indikator: penerangan di tempat kerja, sirkulasi udara di tempat kerja, kebisingan tempat kerja, bau tidak sedap dan keamanan. Variabel bebas motivasi kerja diukur dengan 5 indikator: kebutuhan fisiologis, kebutuhan rasa aman, kebutuhan sosial, kebutuhan penghargaan dan kebutuhan aktualisasi diri. Variabel stres kerja diukur oleh 3 indikator yakni beban kerja, waktu yang terbatas dan karakteristik pekerjaan. Variabel terikat kinerja diukur oleh 3 indikator yakni kualitas kerja, kuantitas kerja dan ketepatan kerja.

e. Kerangka konseptual

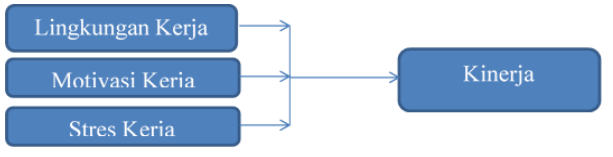

\section{Gambar 1. Kerangka konseptual penelitian}

f. Rujukan penelitian

1 : Asigele Oswald (2012)

2 : Christabella P. bushiri (2014)

3 : Nur Zainie dan Narehan (2015)

4 : Gitahi Njenga (2015)

5 : Thushel Jayaweera (2015)

6 : Sri Nurnaningsih (2016)

7 : Yuliana Tabitha Sari (2016)

8 : Noviansyah (2015)

9 : Tri Wartono (2017)

g. Hipotesis penelitian

H1: Diduga Lingkungan Kerja, Motivasi dan Stres kerja berpengaruh signifikan terhadap Kinerja Pegawai Dinas Perpustakaan dan Kearsipan Kabupaten Malang.

$\begin{array}{rrr}\text { H2: Diduga } & \begin{array}{c}\text { Lingkungan } \\ \text { pengaruh }\end{array} \\ \text { mempunyai } & \text { yang }\end{array}$


dominan terhadap Kinerja Pegawai Dinas Perpustakaan dan Kearsipan Kabupaten Malang.

\section{HASIL DAN PEMBAHASAN}

a. Karakteristik responden

Jenis kelamin kebanyakan responden yang mengisi kuesioner adalah perempuan dengan total 31, pada tingkat usia 20 sampai dengan 60 tahun dan dengan tingkat pendidikan tamatan SLTA sampai dengan S2 dengan masa kerja kebanyakan antara 1-10 tahun. Dengan melihat masa kerja peneliti meyakini bahwa unit yang dianalisis memahami tentang tugas dan tanggung jawab di lingkungan pekerjaannya.

b. Pengujian instrumen

Hasil pengujian butir pertanyaan terhadap variabel yang diukur dinyatakan valid dan relibel. Setiap nilai $r$ hitung lebih besar dari $r$ table $(0,266)$ demikian pula nilai chronbach's Alpha lebih besar dari $r$ tabel $(0,60)$.

c. Analisis Regresi Linier Berganda

Dari hasil pengolahan data dengan menggunakan bantuan komputer program SPSS 20 for windows diperoleh hasil analisis seperti dalam tabel berikut :

\begin{tabular}{|c|c|c|c|c|}
\hline Variabel & $\begin{array}{c}\text { Koefisien } \\
\text { Regresi }\end{array}$ & thitung & Sig. & Keterangan \\
\hline $\begin{array}{l}\text { Lingkungan } \\
\text { kerja (X1) } \\
\text { Motivasi } \\
(\mathrm{X} 2) \\
\text { Stres (X3) }\end{array}$ & $\begin{array}{c}-0.217 \\
0.632 \\
0.414\end{array}$ & $\begin{array}{c}- \\
1.245 \\
6.180 \\
3.623\end{array}$ & $\begin{array}{l}0.219 \\
0.000 \\
0.001\end{array}$ & $\begin{array}{c}\text { Tidak } \\
\text { signifikan } \\
\text { Signifikan } \\
\text { Signifikan }\end{array}$ \\
\hline $\begin{array}{l}\text { Konstanta } \\
\mathrm{R} \\
\text { Adjusted } R \\
\text { square } \\
\mathrm{F}_{\text {hitung }} \\
\text { Sig. F } \\
\mathrm{n}\end{array}$ & $\begin{array}{l}-3.583 \\
0.725 \\
0.498 \\
19.195 \\
0 \\
56\end{array}$ & & & \\
\hline \multicolumn{5}{|c|}{ Variabel terikat $=$ Kinerja Pegawai $(\mathrm{Y})$} \\
\hline \multicolumn{5}{|c|}{$\mathrm{F}$ tabel $=2.77$} \\
\hline $\mathrm{t}$ tabel $=1.6$ & & & & \\
\hline
\end{tabular}

\section{Tabel 1. Rekapitulasi Hasil Analisis Regresi Linier Berganda}

Berdasarkan tabel rekapitulasi tersebut, maka diperoleh persamaan regresi berganda sebagai berikut :

$$
Y=-3,583-0,217 X 1+0,632 X 2+0,414 X 3
$$

Berdasarkan persamaan tersebut dapat dijelaskan sebagai berikut :
$\mathrm{a}=$
$-3,583$ adalah
artinya bahwa apabila
konstanta yang
semua variabel

bebas lingkungan kerja (X1), motivasi kerja (X2), dan stres kerja (X3) adalah 0, maka besarnya variabel kinerja karyarwan sebesar $-3,583$.

$b_{1}=\quad-0,217$ adalah besarnya koefisien regresi variabel bebas lingkungan kerja (X1), koefisien regresi berganda negatif tetapi nilai signifikan lebih besar dari 0,05 ini menunjukkan lingkungan kerja tidak berpengaruh searah terhadap kinerja pegawai, artinya lingkungan kerja yang sudah terbentuk dengan baik tidak menyebabkan kinerja pegawai mengalami peningkatan, dengan anggapan variabel motivasi (X2) dan stres (X3) besarnya tetap. Sedangkan lingkungan kerja terhadap kinerja pegawai sebesar -0,217.

$b_{2}=0.632$ adalah besarnya koefisien regresi variabel bebas motivasi (X2), koefisien regresi berganda positif menunjukkan motivasi berpengaruh searah terhadap kinerja pegawai, artinya semakin baik motivasi akan menyebabkan kinerja pegawai rnengalami peningkatan, dengan anggapan variabel lingkungan kerja (X1) dan stres kerja (X3) besarnya tetap. Sedangkan pengaruh motivasi kerja terhadap kinerja pegawai sebesar 0.632.

$b_{3}=0.414$ adalah besarnya koefisien regresi variabel bebas stres (X3), koefisien regresi berganda positif menunjukkan stres berpengaruh searah terhadap kinerja pegawai, artinya semakin baik keadaan stres akan menyebabkan kinerja pegawai rnengalami peningkatan, dengan anggapan variabel lingkungan kerja (X1) dan motivasi kerja (X2) besarnya tetap. Sedangkan pengaruh motivasi kerja terhadap kinerja pegawai sebesar 0.414 .

Nilai koefisien korelasi berganda (R) sebesar 0,725 menunjukkan adanya hubungan antara lingkungan kerja (X1), motivasi kerja (X2), dan stres kerja (X3) tetapi tidak bersama-sama berpengaruh terhadap kinerja pegawai $(Y)$.

Dari hasil perhitungan regresi berganda di atas, dapat diketahui nilai koefisien determinasi (Adjusted $R$ square) sebesar 0,498. Koefisien determinasi ini mempunyai arti bahwa lingkungan kerja (X1), motivasi kerja (X2), dan stres kerja (X3) tidak bersama-sama mampu memberikan kontribusi terhadap kinerja pegawai.

d. Uji Hipotesis

1. Pengujian Hipotesis Pertama

Untuk menguji hipotesis pertama yang menyatakan bahwa Lingkungan kerja, Motivasi kerja dan Stres kerja berpengaruh signifikan terhadap Kinerja di Lingkungan Dinas Perpustakaan dan Kearsipan Kabupaten Malang, dengan menggunakan 
uji $F$. Dari hasil perhitungan analisis regresi berganda dengan SPSS diperoleh $F_{\text {hitung }}$ sebesar 19,195,sedangkan $F_{\text {tabel }}$ pada $\alpha=$ $5 \%, \mathrm{df}_{1}=3$, dan $\mathrm{df}_{2}=52$ sebesar 2,77 ; hal ini berarti $F_{\text {hitung }}>F_{\text {tabel }} \quad(19,195>2,77)$ sedangkan nilai probabilitasnya lebih kecil dari $\alpha=0,05(0,00<0,05)$, maka Ho di tolak dan Ha di terima yang berarti bahwa variabel bebas : Lingkungan kerja, Motivasi kerja dan Stres kerja berpengaruh signifikan terhadap Kinerja pegawai. Dengan demikian hipotesis pertama secara statistik di terima.

2. Pengujian Hipotesis Kedua

Untuk menguji hipotesis kedua yang menyatakan Lingkungan kerja mempunyai pengaruh yang dominan terhadap Kinerja Pegawai di Lingkungan Dinas Perpustakaan dan Kearsipan Kabupaten Malang, dengan menggunakan uji t. Uji t digunakan untuk menguji apakah masingmasing variabel bebas Lingkungan kerja, Motivasi kerja dan Stres kerja secara parsial berpengaruh signifikan terhadap Kinerja pegawai, dengan cara membandingkan antara $t_{\text {hitung }}$ dengan $t_{\text {tabel }}$. Hasil perhitungan $t_{\text {hitung }}$ dan $t_{\text {tabel }}$ masingmasing variabel bebas adalah sebagai berikut :

\begin{tabular}{|l|c|c|c|c|}
\hline \multicolumn{1}{|c|}{ Variabel } & $\mathrm{t}_{\text {hitung }}$ & $\mathrm{t}_{\text {tabel }}$ & Sig. & Keterangan \\
\hline $\begin{array}{l}\text { Lingkungan } \\
\text { Kerja (X1) }\end{array}$ & -1.245 & 1.672 & 0.219 & $\begin{array}{c}\text { Tidak } \\
\text { signifikan }\end{array}$ \\
\hline $\begin{array}{l}\text { Motivasi } \\
\text { (X2) }\end{array}$ & 6.180 & 1.672 & 0.000 & Signifikan \\
\hline Stres (X3) & 3.623 & 1.672 & 0.001 & Signifikan \\
\hline
\end{tabular}

Tabel 2. Hasil Analisis Regresi Linier Berganda

Dari tabel di atas dapat dijelaskan sebagai berikut :

1) Variabel lingkungan kerja ( $X 1)$

Hasil analisis regresi diperoleh nilai $t_{\text {hitung }}=-1.245$ sedangkan nilai $t_{\text {tabel }}=$ 1,672 sehingga $t_{\text {hitung }}<t_{\text {tabel }}$ atau nilai signifikansi $0.219>0,05$ jadi Ho diterima atau $\mathrm{Ha}$ ditolak, dan terbukti variabel lingkungan kerja (X1) tidak berpengaruh signifikan terhadap kinerja pegawai $(\mathrm{Y})$.

2) Variabel motivasi (X2)

Hasil analisis regresi diperoleh nilai $\mathrm{t}_{\text {hitung }}=6.180$ sedangkan nilai $\mathrm{t}_{\text {tabel }}=$ 1,672 sehingga $t_{\text {hitung }}>t_{\text {tabel }}$ atau nilai signifikansi $0.000<0,05$ jadi Ho ditolak atau $\mathrm{Ha}$ diterima, dan terbukti variabel motivasi (X2) berpengaruh signifikan terhadap kinerja pegawai $(Y)$.

3) Variabel stres (X3)
Hasil analisis regresi diperoleh nilai $t_{\text {hitung }}=3.623$ sedangkan nilai $t_{\text {tabel }}=1,672$ sehingga $t_{\text {hitung }}>t_{\text {tabel }}$ atau nilai signifikansi $0,001<0,05$ jadi Ho ditolak atau Ha diterima, dan terbukti variabel stres (X3) berpengaruh signifikan terhadap kinerja pegawai $(\mathrm{Y})$.

Berdasarkan hasil uji t tersebut di atas, rnaka dapat dibuktikan bahwa lingkungan kerja tidak berpengaruh signifikan terhadap kinerja pegawai, motivasi dan stres secara parsial berpengaruh signifikan terhadap kinerja pegawai (Y). Sedangkan untuk mengetahui variabel yang berpengaruh dominan dengan melihat besarnya koefisien regresi yang berpengaruh signifikan terhadap kinerja pegawai. Variabel bebas yang memiliki koefisien paling besar dan signifikan rnerupakan variabel yang berpengaruh dominan terhadap kinerja pegawai. Berdasarkan hasil analisis regresi berganda dapat diketahui bahwa nilai koefisien regresi terbesar yaitu motivasi sebesar 0.632 , hal ini berarti motivasi merupakan variabel yang berpengaruh dominan terhadap kinerja karyarwan. Sedangkan stres berpengaruh signifikan dan lingkungan kerja tidak berpengaruh signifikan terhadap kinerja pegawai. Dengan demikian hipotesis kedua secara statistik ditolak.

\section{e. Pembahasan}

1. Pengaruh Lingkungan Kerja terhadap Kinerja Pegawai

Menciptakan Lingkungan kerja yang bersih dan nyaman adalah tugas dari perusahaan agar pegawai yang bekerja lebih semangat dalam mengerjakan tugas mereka. Lingkungan kerja lebih ditekankan pada kondisi atau suasana kantor seperti penerangan, udara dan kebersihan. Pegawai merasa nyaman dalam bekerja apabila lingkungan kantor atau ruangannya bersih dan mempunyai sirkulasi udara yang baik. Dalam hasil penelitian ini menemukan bahwa lingkungan kerja yang tercipta di Dinas Perpustakaan dan Kearsipan Kabupaten Malang telah terbentuk dengan baik sehingga tidak berpengaruh signifikan terhadap kinerja pegawai. Hasil penelitian ini tidak sesuai dengan penelitian yang dilakukan oleh Asigele, Christabella, Nur Zainie, Gitahi dan Thushel yang menemukan bahwa lingkungan kerja berpengaruh signifikan terhadap kinerja pegawai, dalam penelitian ini menemukan lingkungan kerja tidak berpengaruh signifikan. 
2. Pengaruh Motivasi terhadap Kinerja Pegawai

Dorongan untuk melakukan sesuatu menyebabkan individu berperilaku dalam cara-cara tertentu, membangkitkan antusiasme dan perlawanan untuk melakukan serangkaian tindakan tertentu. Motivasi yang tercipta baik dari pimpinan maupun individu itu sendiri berbeda-beda, akan tetapi motivasi yang baik harus diciptakan oleh pimpinan sehingga pegawai merasakan semangat dalam bekerja dan menunjang pekerjaan mereka menjadi lebih baik. Hasil penelitian ini sejalan dengan Sri Nurnaningsih (2016) yang menyatakan bahwa motivasi berpengaruh terhadap kinerja pegawai, begitu juga dengan Tabitha Sari (2016) yang juga menyatakan bahwa motivasi berpengaruh terhadap kinerja pegawai.

3. Pengaruh Stres terhadap Kinerja Pegawai

Stres mempengaruhi keadaan kerja seseorang, baik stres yang berasal dari dalam organisasi maupun luar organisasi. Posisi stres sangatlah penting dalam mempengaruhi kinerja pegawai, oleh karena itu perlu disadari dan dipahami keberadaannya, penting untuk mengetahui sumber-sumber stres dan cara mengatasinya sehingga kinerja pegawai dapat optimal dan kelangsungan hidup organisasi yang sehat. Hasil penelitian ini sesuai dengan penelitian yang dilakukan oleh Tri Wartono dan Noviansyah yang menemukan bahwa stres mempunyai pengaruh yang signifikan dan positif terhadap kinerja, yang berarti apabila stres meningkat maka kinerja pegawai juga meningkat.

\section{KESIMPULAN}

1. Lingkungan kerja yang bersih, penerangan yang baik dan sirkulasi udara yang baik merupakan faktor yang sangat penting dalam meningkatkan kinerja pegawai. Pegawai akan merasa nyaman dalam bekerja jika di dalam ruangan maupun di lingkungan kerja mereka memenuhi ketiga faktor diatas, hal tersebut perlu dipertahankan oleh pimpinan dan seluruh pegawai sehingga tetap tercipta rasa kerja yang nyaman. Dalam hasil penelitian ini menemukan bahwa Lingkungan kerja tidak berpengaruh signifikan terhadap kinerja pegawai.

2. Motivasi atau dorongan merupakan hal yang sangat penting di dalam suatu organisasi, motivasi dalam suatu lingkungan kerja diciptakan oleh atasan, sehingga jika motivasi yang diciptakan baik maka akan berpengaruh kepada kinerja pegawai, begitu pula sebaliknya apabila motivasi yang diciptakan buruk maka akan menurunkan semangat kerja dari pegawai. Hubungan yang baik antara pimpinan dan pegawai, pimpinan yang menghargai hasil kerja pegawai dan pegawai yang merasa dihormati dalam bekerja adalah suatu hal yang sudah diciptakan pimpinan dengan baik dalam Lingkungan Dinas Perpustakaan dan Kearsipan Kabupaten Malang, pegawai merasa hal tersebut sudah baik. Dalam hasil penelitian ini menjelaskan bahwa motivasi berpengaruh dominan dan signifikan terhadap kinerja pegawai, sehingga pimpinan perlu memperhatikan, menjaga dan meningkatkan motivasi pegawai.

3. Pekerjaan yang membutuhkan lebih banyak personil dan deadline pekerjaan yang cepat membuat pegawai merasa stres di Lingkungan Dinas Perpustakaan dan Kearsipan Kabupaten Malang. Pimpinan perlu memperhatikan hal ini dikarenakan stres dapat mempengaruhi kinerja pegawai. Dalam penelitian ini menjelaskan bahwa Stres berpengaruh signifikan terhadap kinerja pegawai, sehingga semakin tinggi tingkat stres maka semakin tinggi juga mempengaruhi kinerja pegawai.

4. Variabel Lingkungan Kerja memiliki ratarata sebesar 2,95 dan tidak berpengaruh signifikan terhadap Kinerja, sedangkan variabel Stres Kerja memiliki rata-rata sebesar 3,12 dan berpengaruh signifkan terhadap Kinerja, Motivasi memiliki ratarata sebesar 3,72 dan berpengaruh serta dominan terhadap Kinerja Pegawai.

\section{REFERENSI}

Anathan, L dan Ellitan, L. 2007. Manajemen Sumber Daya Manusia Dalam Bisnis Modern. Alfabeta : Bandung.

As'ad, Mohammad. 2001. Psikologi Industri. Liberty: Yogyakarta.

Bushiri, C.P. 2014. The impact of working environment on employees' performance, the case of Institute of Finance Management in Dar es Salaam. Human Resource Management of the open university of Tanzania.

Gibson, J.L. 2003. Struktur Organisasi dan Manajemen. Organisasi : Binarupa Aksara : Jakarta.

Ghozali, Imam, 2007 Aplikasi Analisis Multivariate dengan Program SPSS. Badan Penerbit UNDIP : Semarang.

Gomes, F. Cardosa. 2003. Manajemen Sumber Daya Manusia. Yogyakarta. Andi Offset : Yogyakarta.

Grifin, R.W. 2003. Manajemen. Erlangga : Jakarta. 
Handoko, T.H. 2008. Manajemen Personalia. BPFE : Yogyakarta.

Handoko, T.H. 2001. Manajemen Personalia dan Sumber Daya Manusia. BPFE Press : Yogyakarta.

Hasibuan, Malayu. 2007. Manajemen Sumber Daya Manusia. Bumi Aksara : Jakarta. 2003. Organisasi dan Motivasi. Dasar Peningkatan Produktivitas. Bumi Aksara : Jakarta.

Jayaweera, Thushel. 2015. Impact of Work Environmental Factors on Job Performance, Mediating Role of Work Motivation: A Study of Hotel Sector in England.

Looker, Terry. 2005. Managing Stres. Andi : Yogyakarta.

Luthans, Fred. 2006. Organizational Behaviour Edisi 10. Terjemahan oleh Vivin Andhika Yuwono,Shekar Purwanti,dkk.2006. Penerbit Andi: Yogyakarta.

$$
\text { 2003. Organization Behaviour. }
$$

Erlangga: Jakarta.

Mangkunegara, A.A. Anwar Prabu. 2007. Manajemen Sumber Daya Manusia Perusahaan. PT. Remaja Rosdakarya. Bandung. 2006. Evaluasi Kinerja Sumber Daya Manusia. PT: Refika Aditama : Bandung. 2005. Evaluasi Kinerja SDM. PT. Refika Aditama: Bandung.

Mathis, Robert L. dan Jackson. John H. 2006. Human Resource Management (Manajemen Sumber Daya Manusia). Edisi 10. Jakarta: Salemba Empat.

Nazir M. 2008. Metode Penelitian. Ghalia Indonesia : Jakarta.

Njenga, Gitahi Samson, Maina Waiganjo. 2015. Effect of Workplace Environment on the performance of Commercial Banks Employess in Nakuru Town.

Noviansyah. 2015. Pengaruh Stres Kerja dan Motivasi Kerja terhadap Kinerja Karyawan PT. Perkebunan Minanga Ogan Baturaja. Universitas Baturaja

Nurnaningsih, S. 2016. Pengaruh Pelatihan, Kompensasi, dan Motivasi kerja terhadap Kinerja Anggota DPRD Kota Banjarmasin. Universitas Merdeka Malang.

Oswald, A. 2012. The Effect of Working Environment on Workers Performance: The case of Reproductive and Child Health care providers in Tarime district. University of Health and Allied Sciences.

Robbins, Stephen, P. 2003. Prinsip-Prinsip Perilaku Organisasi. Jakarta: Erlangga.
Sanusi , Anwar. 2014. Metodologi Penelitian Bisnis. Cetakan Kelima. Penerbit Salemba Empat : Jakarta.

Sedarmayanti. 2009. Tata Kerja dan Produktivitas Kerja. Mandar Maju : Bandung.

Siagian, Sondang P. 2004. Teori Motivasi Dan Aplikasinya. Cetakan Ketiga. Rineka Cipta : Jakarta. 2003. Manajemen Sumber Daya

Manusia. Bumi Aksara: Jakarta. 2001. Manajemen Sumber Daya

Manusia. Bumi Aksara : Jakarta.

Sofyandi dan Garniwa. 2007. Perilaku Organisasional. Edisi Pertama. Graha Ilmu : Yogyakarta.

Sudarmanto. 2009. Kinerja Dan Pengembangan Kompetensi SDM. Cetakan Pertama. Pustaka Pelajar : Yogyakarta.

Suwatno. 2011. Manajemen Sumber Daya Manusia. Alfabeta : Bandung.

Tabitha, Y.S. 2016. Pengaruh Kompetensi dan Motivasi terhadap Kinerja Karyawan Bank Mega kantor cabang Lambung. Universitas Merdeka Malang.

Wartono, Tri. 2017. Pengaruh Stres Kerja terhadap Kinerja Karyawan Majalah Mother and Baby. Jurnal IImiah Prodi Manajemen Universitas Pamulang.

Wursanto, Ig. 2005. Dasar-Dasar IImu organisasi. Andi Offset : Yogyakarta.

Zainie, N. Narehan. 2015. The Relationship Between Workplace Environment and Job Performance in Selected Government Offices in Shah Alam, Selangor. Faculty of Business Management Universiti Teknologi MARA. 